Гапон В. В.

кандидат педагогічних наук, начальник відділу інформаційно-аналітичних систем ДНУ «Інститут освітньої аналітики», Київ, Україна, gароп@топ.gov.иа

\title{
Чимбай Л. Л.
}

завідувач сектору системного та телекомунікаційного забезпечення ДНУ «Інститут освітньої аналітики», Київ, Україна, __chimbay@топ.gov.иа

Барабаш 0. А.

завідувач сектору фінансово-економічної звітності днУ «Інститут освітньої аналітики», Київ, Україна, о_barabash@топ.gov.иа

\section{ДОСВІД РОЗРОБЛЕННЯ ТА ФУНКЦІОНУВАННЯ РОЗПОДІЛЕНОЇ ІНФОРМАЦІЙНОЇ БАЗИ ДАНИХ З ОРГАНІЗАЦІЙНО-РОЗПОРЯДЧОЮ ІНФОРМАЦІЄЮ МIНІСТЕРСТВА ОСВІТИ І НАУКИ УКРАЇНИ}

Анотація. Викладено інформацію про досвід створення розподіленої бази даних з організаційно-розпорядчими та нормативно-правовими документами Міністерства освіти і науки Украӥни, що регламентують діяльність системи освіти і науки. Проаналізовано основні етапи створення і особливості підтримки інформаційно-пошукової системи, визначено критерії вибору технічної платформи побудови інформаційної бази даних та показники, за якими виконується структуризація інформації.

Ключові слова: інформаційно-пошукова система, реляційна база даних, система освіти, електронний документ.

Рис. 4. Табл. 2. Літ. 8.

JEL classification: I28, Y10.

Останніми роками особливу увагу в освітній галузі приділяють питанням іï розвитку і реформування, поліпшенню якості освіти, їі доступності та конкурентоспроможності. Засади забезпечення якості освіти та освітньої діяльності проголошено у прийнятому 5 вересня 2017 р. Законі України «Про освіту» [1]. Одним з найважливіших завдань напряму реформування освіти визначено вдосконалення системи управління освітою. Першочергове завдання будь-якої ре- форми полягає в удосконаленні законодавчого регулювання, розробленні численних проектів законодавчих актів, внесенні змін до діючих нормативно-правових актів. Це значною мірою потребує посилення інформаційної підтримки діяльності як галузевих органів державної влади, так і органів управління закладами освіти. Як зазначено в Рекомендаціях парламентських слухань на тему «Реформи галузі інформаційно-комунікаційних технологій та розвиток інформацій-

(c) Гапон В. В., Чимбай Л. Л., Барабаш О. А., 2018 
ного простору України» [2], в умовах глибинного та динамічного проникнення інформаційно-комунікаційних технологій (IКТ) в усі сфери життєдіяльності особи, суспільства, держави проблемою залишається низький рівень впровадження та використання можливостей ІКТ у сферах освіти, науки, культури та охорони здоров'я. Виконання окреслених завдань неможливе без формування впорядкованих банків 3 організаційно-розпорядчою i правовою урядовою та галузевою документацією, вільного доступу до існуючих інформаційних та нормативно-правових ресурсів, підвищення рівня інтеграції ІКТ в освітню галузь.

Питання функціонування сучасних держав в умовах глобалізації вивчали зарубіжні вчені Т. Геблер, А. Альберті, В. Беккерс та ін. Наукові розробки щодо формування інформаційно-комунікаційних систем здійснювали зарубіжні вчені Ф. Котлер та Е. Райс. Питанням створення інформаційно-комунікаційних систем присвячені праці українських вчених М. Згуровського, В. Галагана, М. Домбругова, Ю. Якименка, В. Тимофєєва (зокрема розбудові Національної освітньо-телекомунікаційної мережі «УРАН») [3], дослідженню переваг використання ІКТ в Україні - Н. Шпака. Проблематику створення впорядкованого банку нормативних документів та методичних матеріалів, що забезпечують інформаційну підтримку управлінської діяльності у закладах вищої освіти, досліджували науковці А. Гуржій [4], В. Биков, Н. Задорожна [5], О. Овчарук, Н. Морзе, О. Співаковський [6], I. Король, Я. Булахова, О. Бондаренко, В. Заболотний.

Мета цієї статті - проаналізувати інформацію про здобутий досвід створення повнотекстової системи електронних документів 3 організаційно-розпорядчою та нормативно-правовою інформацією Міністерства освіти і науки України (МOH), що регламентує діяльність системи освіти і науки.

На сучасному етапі переходу світового співтовариства до інформаційного суспільства ступінь розвитку інформаційного простору та інформаційних технологій стає безпосереднім чинником національної конкурентоспроможності. Про важливе значення використання ІКТ свідчать програми розвитку багатьох держав, зокрема Стратегія соціально-економічного розвитку Європейського Союзу на період до 2020 року «Європа 2020», яку було прийнято на саміті лідерів країн Євросоюзу (2010р., Брюссель).

Інформаційні ресурси - одна з основних складових інформаційно-комунікаційних систем, що забезпечує доступ, обмін інформацією та її опрацювання. Інтеграція ІКТ у галузь освіти не лише впливає на освітні й управлінські процеси, а й вводить нові, пов'язані із застосуванням комп'ютерів, телекомунікацій, спеціального обладнання, засобів інформаційного обміну, систем опрацювання інформації. Створюються нові засоби навчання та збереження ресурсів, до яких належать електронні підручники та мультимедіа; електронні бібліотеки та архіви, глобальні та локальні освітні мережі; інформаційно-пошукові та інформаційно-довідкові системи та ін.

У цій статті проаналізовано етапи та особливості створення і підтримки інформаційно-пошукової системи (IПC) 3 нормативно-правовими актами МОН. 
Основними були такі етапи створення ІПС:

- вивчення й надбання досвіду 3 розроблення та експлуатації розподілених інформаційних систем;

- розроблення засобів для зберігання, опрацювання та відкритого доступу до інформаційних ресурсів 3 організаційно-розпорядчою та нормативно-правовою інформацією $\mathrm{MOH}$;

- приєднання закладів вищої освіти та установ освіти і науки до цього інформаційного ресурсу;

- впровадження ефективного інформаційного управління освітою і наукою;

- збирання, опрацювання, зберігання нормативно-правових та науково-методичних документів, що визначають організацію освітнього процесу, управління освітньою і науковою діяльністю закладів вищої освіти.

3 метою дослідження та розроблення сучасних технологій текстового пошуку використовували такі інструменти:

- лінгвістичний аналіз текстів;

- статистичні методи;

- математичну логіку та теорію ймовірностей;

- кластерний аналіз;

- технології керування даними.

Пропоновані цілі та завдання певною мірою відтворені при розробленні першого етапу проекту, який почався у 2000 р. На цьому етапі проаналізували концепцію, архітектуру, ресурси та методи побудови сучасних інформаційних розподілених баз даних (РБД).

Методологія проектування баз даних передбачає три основних фази [7]:

- концептуальну;

- логічну;

- фізичну.
Концептуальне проектування - це конструювання інформаційної моделі бази незалежно від фізичних параметрів реалізації, наприклад, системи керування базами даних (СКБД), особливостей прикладних програм, мови програмування та обчислювальної платформи.

Концептуальну модель РБД показано на рис. 1.

Розподілена база даних - це сукупність логічно взаємопов'язаних баз даних або частин однієї бази, розпаралелених між кількома територіально розподіленими ПК і забезпечених відповідними можливостями для керування цими базами або їх частинами. Іншими словами, розподілена база даних реалізується на розміщених у різних місцях обчислювальних засобах разом з організаційним, технічним і програмним забезпеченням її створення та ведення.

Використовувати РБД доцільно i ефективно у предметних областях 3 надто великими обсягами даних, що зберігаються i опрацьовуються; фізичним рознесенням даних за місцями збирання, зберігання та використання; наявністю розвинутих засобів обчислювальної техніки і мереж передавання даних; можливістю опрацювання більшої частини інформації в місцях, де вона виникає або зберігається; необхідністю одночасного масового опрацювання інформації.

у фазі логічного проектування баз даних концептуальні моделі перетворюються на локальні логічні моделі даних, структура яких визначається вибраним класом цільової СКБД.

Логічна структура РБД є адекватним відтворенням отриманої інфор- 


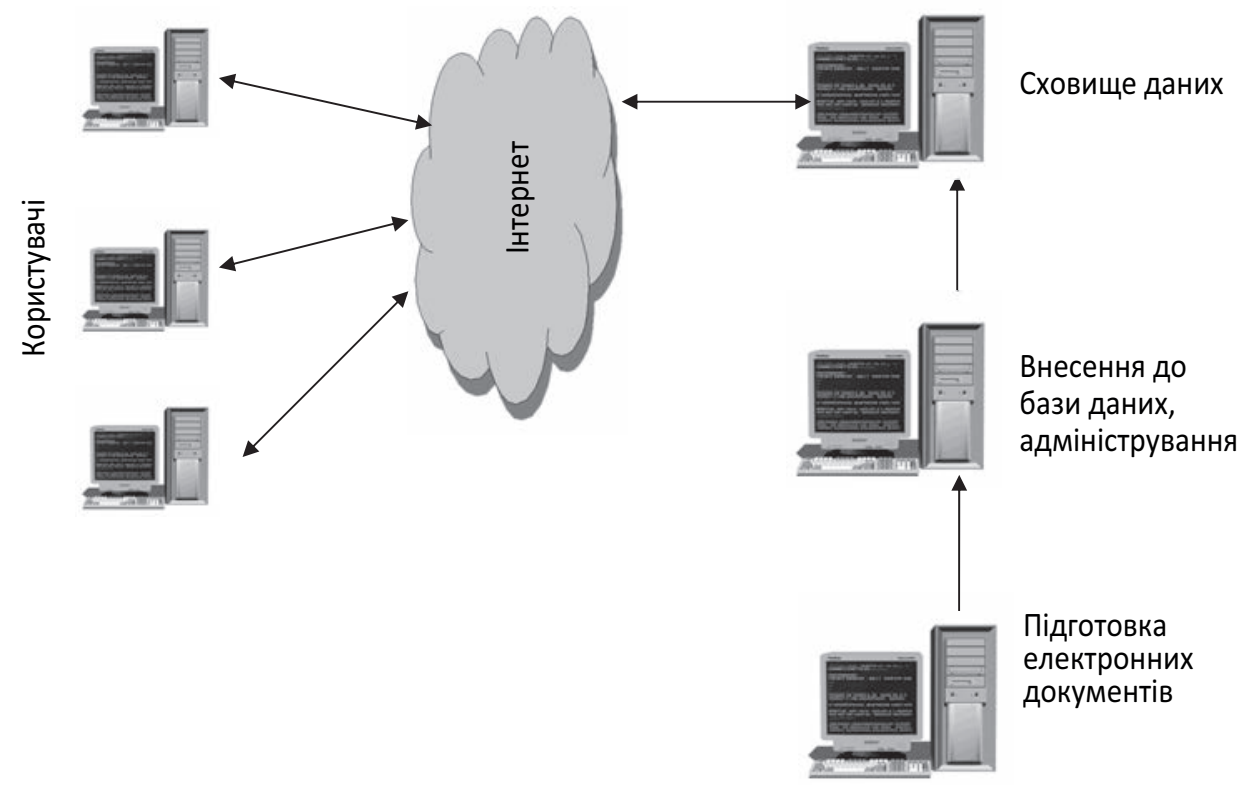

Рис. 1. Концептуальна модель реляційної РБД

Побудовано авторами.

маційно-логічної моделі, що не потребує додаткових перетворень. Кожний інформаційний об'єкт моделі даних відображається відповідною реляційною таблицею. Структура реляційної таблиці визначається реквізитним складом відповідного інформаційного об'єкта, де кожний стовпець (поле) відповідає одному реквізиту об'єкта. Ключові реквізити утворюють унікальний ключ реляційної таблиці. Для кожного стовпця визначається формат і розмір даних. У розробленій РБД кожний документ характеризується певними реквізитами, такими як категорія (до якої ланки освіти належить документ), тип (наприклад, закон, постанова, наказ), стан документу (чинний, нечинний, зі змінами), які є інформаційними об'єктами.

Базовий варіант побудови єдиного інформаційного простору в системі було вибрано після грунтовних мо- ніторингових досліджень при проектуванні розподіленої інформаційної бази даних з організаційно-розпорядчими та нормативно-правовими документами. Технологічну модель ІПС зображено на рис. 2.

Основні елементи технічного забезпечення функціонування IПС такі:

- центральний ПК (файл-сервер, Web-сервер);

- робочі станції, які використовують як автоматизовані робочі місця адміністратора;

- фізичне середовище передавання даних (наприклад, мережеві адаптери, оптоволоконні лінії, сервери) - забезпечує провайдер;

- ПК користувачів.

Фаза фізичного проектування передбачає прийняття рішення про конкретну реалізацію створюваної бази даних. Отже, фізичне проектування безпосередньо пов'язане з урахуван- 


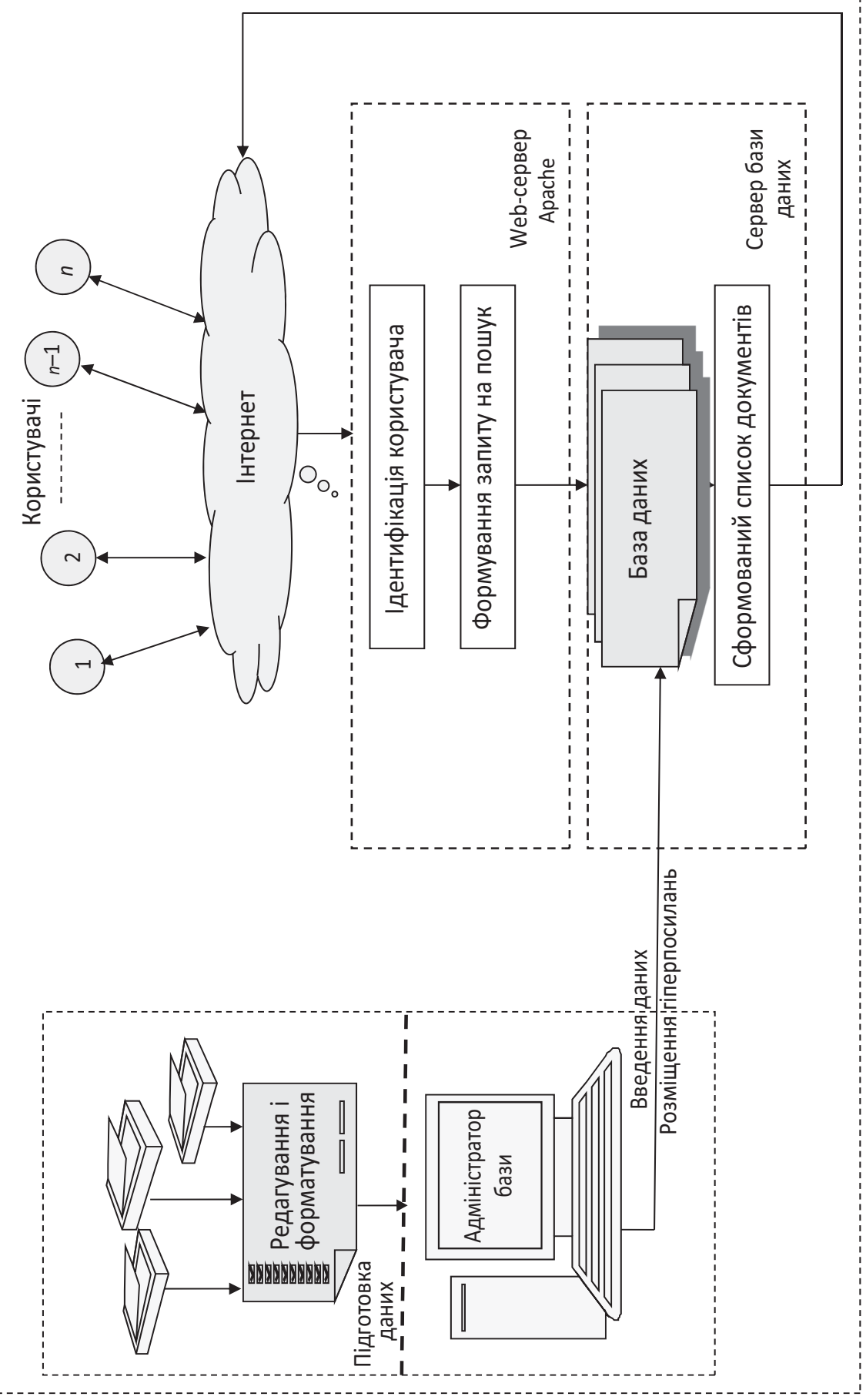

要 
ням особливостей СКБД, конкретним використанням мови програмування, обчислювальною платформою. На цьому етапі можливе повернення до попередніх етапів з метою внесення коректив або доопрацювання.

До основних критеріїв вибору засобів створення РБД належать такі:

- архітектура клієнт-сервер з доступом в Інтернет (тому програмна платформа повинна мати ліцензію або бути з відкритим програмним кодом і поширюватись на безоплатних засадах);

- забезпечення надійної одночасної роботи великої кількості користувачів за мінімальних фінансових витрат;

- простота адміністрування, незалежність від апаратної частини.

Під час дослідження було визначено технологічну платформу, до якої увійшли:

для серверної частини -

- операційна система з відкритим вихідним кодом Linux, що не потребує придбання ліцензії (з виходом нових версій дистрибутиву система оновлюється);

- веб-сервер з відкритим вихідним кодом Apache;

- платформа для серверного програмування - мова РНР;

- СКБД MySQL - реляційна СКБД; дані в її базах зберігаються у вигляді логічно взаємопов'язаних таблиць, доступ до яких здійснюється за допомогою мови запитів SQL;

для клієнтської частини -

- операційні системи Windows будь-якої версії, Linux;

- Web-браузер Internet Explorer, Opera, Mazilla, Google Chrome.

Після розроблення програмного забезпечення РБД останню наповни- ли організаційно-розпорядчими документами МОН, що регламентують діяльність системи освіти і науки, та підключили до неї користувачів (структурні підрозділи МОН, заклади вищої освіти).

Станом на 1 вересня 2018 р. у РБД міститься 25085 документів. Загалом упродовж 2017 р. у РБД було введено 1688 наказів з основної діяльності (обсягом понад 23500 сторінок) та 70 документів інших типів.

Інформацію про наявність класифікованих за типами документів у розподіленій інформаційній базі даних МОН наведено в табл. 1.

Як бачимо, переважну більшість становлять накази МОН з основної діяльності (понад 81 \%). Накази МОН спільно з іншими центральними органами виконавчої влади становлять 5,3 \% загальної кількості документів. До РБД вносять також інструктивнометодичні листи, листи-роз'яснення структурних підрозділів МOH, урядові нормативні документи в галузі освіти. Щороку базу поповнюють 1400-2000 наказів. Загалом інформацію класифіковано за 23 типами. Діаграму розподілу документів за основними типами та їх частки в загальному обсязі документів показано на рис. 3.

Внесені документи класифікують за категоріями відповідно до змісту питань. Загалом визначено 18 основних категорій (табл. 2). Для порівняння в табл. 2 наведено узагальнені дані за п'ять останніх років (2013-2017рр.).

Діаграму розподілу документів за найвагомішими за обсягом категоріями зображено на рис. 4. Як бачимо, близько чверті обсягу РБД становлять накази, що регламентують сферу вищої освіти. Приблизно однакові 


\section{Розподіл документів РБД за типами}

таблищя 1

\begin{tabular}{|l|c|}
\hline \multicolumn{1}{|c|}{ Тип документів } & Загальна кількість документів \\
\hline Документи інших міністерств та відомств & 1023 \\
Доповіді & 1 \\
Закони України & 46 \\
Запитання - відповіді & 4 \\
Інструкції & 27 \\
Комюніке & 3 \\
Листи МОН & 533 \\
Листи МОН спільно з іншими установами & 32 \\
Меморандуми & 2 \\
Накази МОН & 20344 \\
Накази МОН спільно з іншими установами & 1328 \\
Постанови Верхвної Ради України & 41 \\
Постанови Кабінету Міністрів України & 576 \\
Рішення колегії МОН & 160 \\
Розпорядження Кабінету Міністрів України & 265 \\
Розпорядження МОН & 129 \\
Розпорядження Президента України & 49 \\
Угди & 7 \\
Укази Президента України & 202 \\
Статути & 175 \\
Зміни до статутів & 135 \\
Рекомендовані & 2 \\
Положення & 1 \\
Разом & $\mathbf{2 5 0 8 5}$ \\
\hline
\end{tabular}

Складено авторами за інформацією РБД.

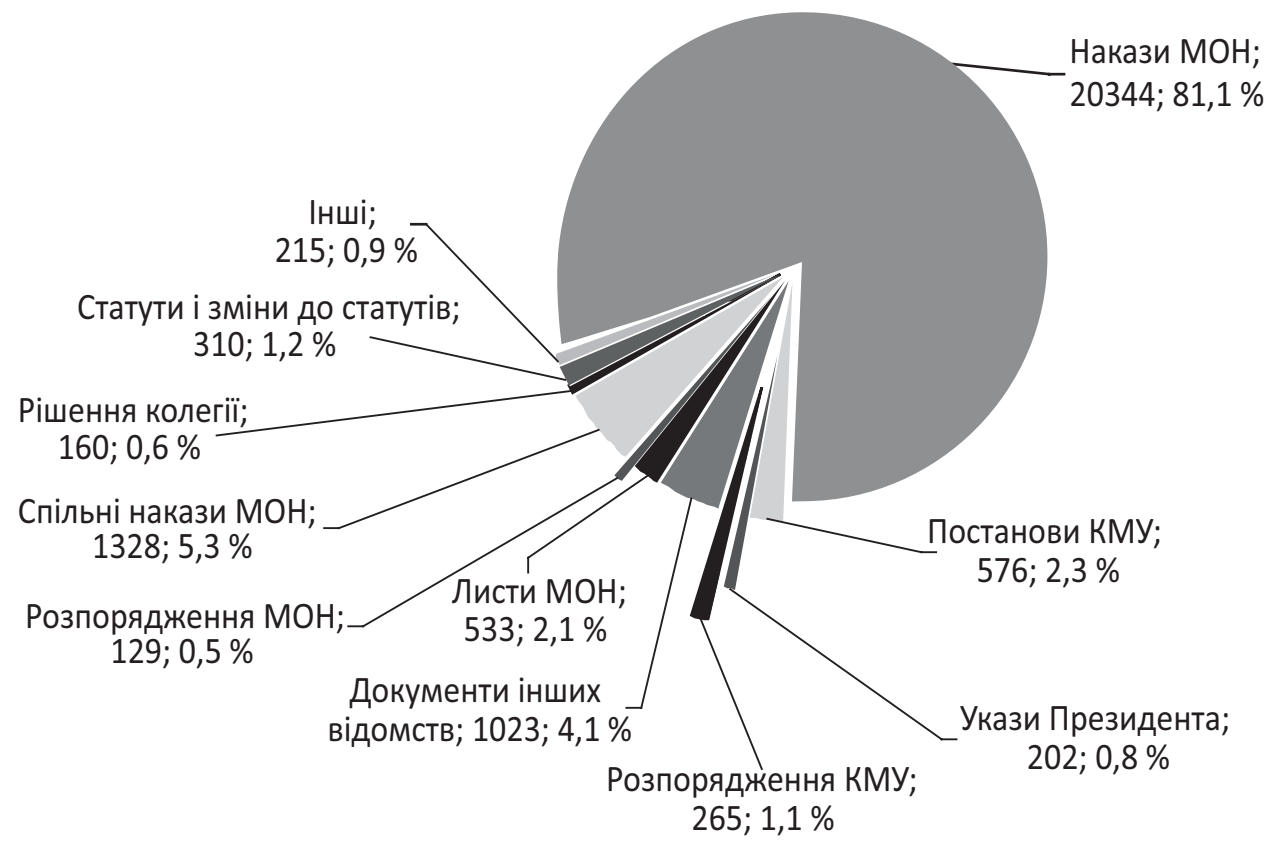

Рис. 3. Розподіл документів у РБД за основними типами

Побудовано авторами за інформацією РБД. 
Класифікація документів РБД за категоріями

таблиия 2

\begin{tabular}{|c|c|c|c|c|c|c|}
\hline \multirow{2}{*}{ Категорія документів } & \multirow{2}{*}{$\begin{array}{c}\text { Загальна } \\
\text { кількість } \\
\text { документів }\end{array}$} & \multicolumn{5}{|c|}{ Загальна кількість документів за роками } \\
\hline & & $2013 \mathrm{p}$. & 2014 p. & 2015 p. & 2016 p. & $2017 p$. \\
\hline Адміністративні питання & 2685 & 270 & 210 & 236 & 241 & 210 \\
\hline Вища освіта & 6076 & 496 & 278 & 304 & 268 & 373 \\
\hline Дистанційна освіта & 16 & 16 & 5 & - & - & 1 \\
\hline Дошкільна освіта & 104 & 14 & 4 & 5 & 7 & 5 \\
\hline Загальна середня освіта & 3000 & 247 & 219 & 236 & 270 & 238 \\
\hline Інші питання & 3330 & 12 & - & 4 & - & - \\
\hline Міжнародні питання & 165 & 14 & 4 & 20 & 22 & 26 \\
\hline Наукові питання & 1050 & 52 & 44 & 81 & 104 & 83 \\
\hline Післядипломна освіта & 530 & 30 & 21 & 22 & 35 & 24 \\
\hline Позашкільна освіта & 909 & 65 & 64 & 60 & 59 & 82 \\
\hline Професійно-технічна освіта & 3253 & 421 & 459 & 290 & 202 & 265 \\
\hline Аспірантура-докторантура & 167 & - & - & 2 & 2 & 3 \\
\hline Самоосвіта & 6 & 1 & - & - & - & - \\
\hline Соціальні питання & 286 & 16 & 24 & 19 & 38 & 35 \\
\hline Фінансові питання & 3256 & 317 & 252 & 174 & 407 & 383 \\
\hline Безпека життєдіяльності & 26 & 3 & 1 & 4 & 3 & 5 \\
\hline Атестація кадрів & 97 & 21 & 24 & 14 & 6 & 8 \\
\hline Спорт & 129 & 30 & 8 & 8 & 17 & 17 \\
\hline Разом & 25085 & 2025 & 1617 & 1479 & 1681 & 1758 \\
\hline
\end{tabular}

Складено авторами за інформацією РБД.

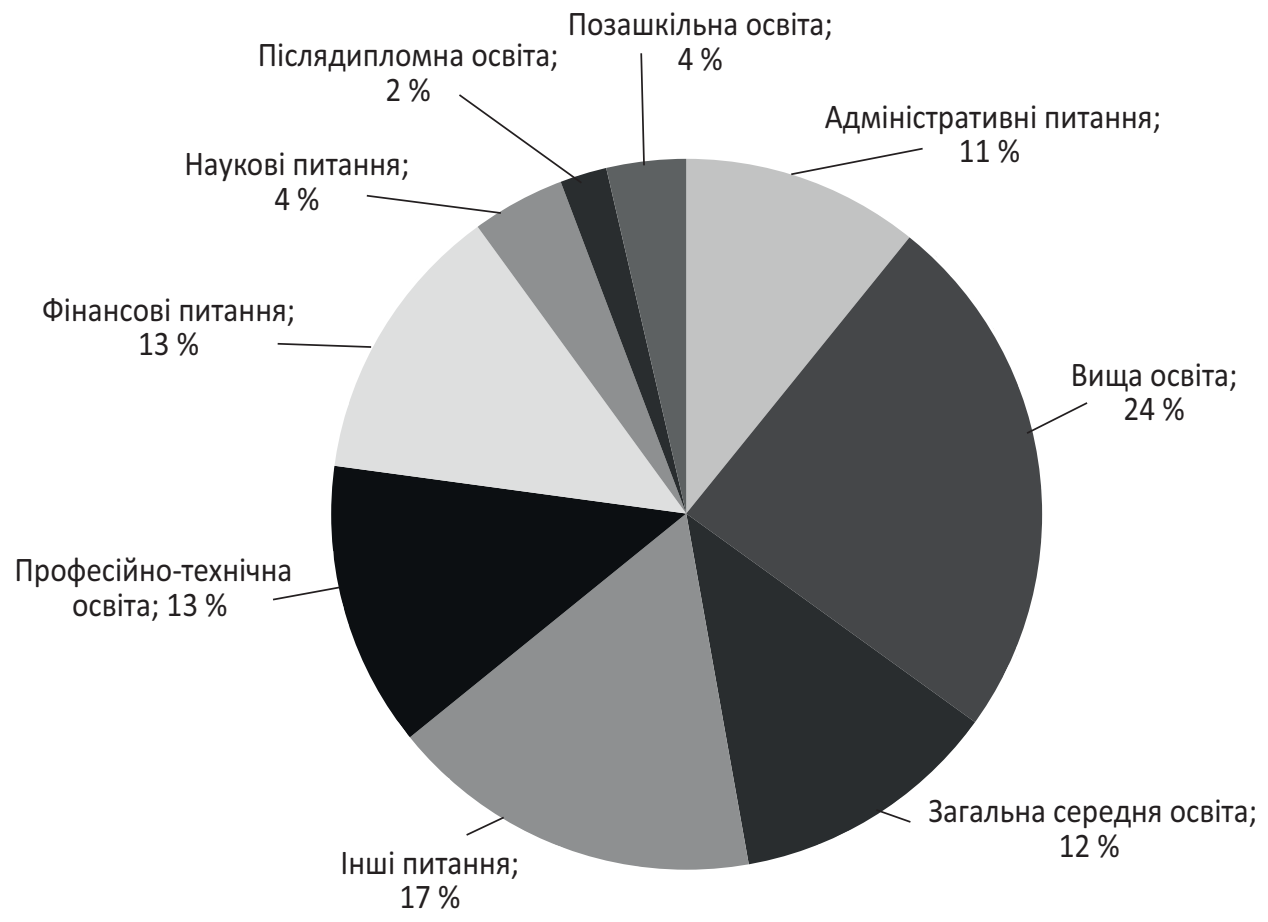

Рис. 4. Розподіл документів у РБД за категоріями

Побудовано авторами за інформацією РБД. 
частки (12,4-13 \%) припадають на загальну середню, професійно-технічну освіту і фінансові питання. Частка наказів 3 адміністративних питань становить 10,6\%.

Згідно з результатами аналізу обсяг опрацьованої інформації (кількість сторінок) щороку збільшувався. Так, у 2015 р. було опрацьовано 16273 сторінок, у 2016 р. - 22098, у 2017 р. - понад 22200.

Новими документами база поповнюється здебільшого двічі на тиждень.

Технологія підготовки, опрацювання та введення інформації включає кілька етапів:

1. Сканування документів. лів.

2. Редагування, форматування фай-

3. Визначення категорії документів.

4. Копіювання інформації на сервер.

5. Введення записів до бази даних, заповнення полів бази.

6. Проставлення гіперпосилань.

7. Ведення документації.

Для користування системою необхідно авторизуватись за ім'ям і паролем. Авторизований вхід запроваджено з метою забезпечення інформаційної безпеки, а також статистичного обліку користуванням інформаційними ресурсами.

Для організації швидкого доступу до інформації РБД документи розподілені за окремими критеріями або їх комбінацією:

- тип документу (наприклад, «Наказ $\mathrm{MOH»);}$

- категорія документу (наприклад, «Вища освіта»);

- номер документу (номер, за яким документ зареєстрований у МОН);

- ключові слова або словосполучення, що входять до назви документу;
- дата реєстрації документу або проміжок дат;

- ключові слова з тексту документу.

Знайдені документи користувач може переглянути, роздрукувати, зберегти на власний ПК.

Зберігаються документи в базі у форматі PDF (Portable Document Format), який $є$ міжнародним стандартом і забезпечує повну відповідність оригіналам.

Отже, використання створеного інформаційного ресурсу з нормативно-правовою документацією МОН в його управлінській діяльності та діяльності підвідомчих навчальних закладів забезпечує:

- працезаощаджувальну технологію адміністративно-управлінських процесів;

- необхідні умови для збільшення частки інтелектуальної продуктивної праці та змістовної роботи з документами і зменшення витрат праці на рутинні операції;

- доступ засобами Інтернет-технологій до інформаційних ресурсів, що регламентують та регулюють освітню політику системи освіти загалом та ї̈ структурних компонент;

- ефективне керування доступом до розподіленої інформаційної бази даних, реалізацію функцій адміністрування.

У сучасних економічних і соціальних умовах впровадження ІКТ та хмарних технологій як провідний визначився напрям розвитку всіх сфер суспільного життя. У схваленій розпорядженням Кабінету Міністрів України від 15.05.2013 № 386-р Стратегії розвитку інформаційного суспільства в Україні визначено базові принципи і стратегічні цілі розвитку інформаційної інфраструктури з ура- 
хуванням сучасних тенденцій та особливостей розбудови суспільства [8].

На виконання завдань Стратегії розвитку електронних інформаційно-аналітичних систем державних органів передбачено подальше вдосконалення організаційного, методологічного, програмного забезпечення ІПС з організаційно-розпорядчою інформацією МОН. У подальшому дослідники планують розробити процедуру забезпечення архівного зберігання електронних документів та використання бази даних для інформаційно-технологічного забезпечення моніторингу освіти.

Одна з найважливіших умов використання IКТ - забезпечення інформаційної безпеки. В умовах збільшення чисельності користувачів науковці досліджують шляхи підвищення рівня захисту електронних інформаційно-аналітичних систем державних органів.

\section{Список використаних джерел}

1. Про освіту : Закон України від 05.09.2017 № 2145-VIII. URL: http://zakon5.rada. gov.ua/laws/show/2145-19.

2. Про Рекомендації парламентських слухань на тему «Реформи галузі інформаційно-комунікаційних технологій та розвиток інформаційного простору України» : постанова Верховної Ради України від 31.03.2016 № 1073-VIII. URL: http://zakon3.rada. gov.ua/laws/show/1073-19.

3. Розбудова національної науково-освітньої телекомунікаційної мережі «УРАН» в рамках державної програми «Інформаційні та комунікаційні технології в освіті та науці» на 2006-2010 роки // Інформаційні технології в освіті : зб. наук. пр. / В. Г. Галаган, М. Р. Домбругов, П. О. Журавков та ін. Херсон. держ. ун-т. 2009. Вип. 4. С. 18-30.

4. Гуржій А. М., Гапон В. В. Сучасний стан впровадження інформаційно-комунікаційних технологій у вищих навчальних закладах України / Вісник Хмельницьк. нац. ун-ту. 2012. № 4. Т. 2. С. 71-75.

5. Досвід розробки і розвитку інформаційних освітніх ресурсів у мережі Інтернет / Н. Т. Задорожна та ін. // Інформаційні технології і засоби навчання : зб. наук. пр. / за ред. В. Ю. Бикова, Ю. О. Жука / Ін-т засобів навчання АПН України. К. Атіка. 2005. С. 272.

6. Інформаційні технології в управлінні вищими навчальними закладами / О. В. Співаковський, Д. Є. Щедролосьєв, Н. М. Чаловська та ін. Херсон. Айлант. 2005. 151 с.

7. Гайдаржі В. І., Дацюк О. А. Основи проектування та використання баз даних. 2-ге вид., виправ. та допов. К. 2004. С. 254.

8. Стратегія розвитку інформаційного суспільства в Україні : розпорядження Кабінету Міністрів України від 15.05.2013 № 386-p. URL: http://zakon4.rada.gov.ua/laws/ show/386-2013-p. 
Valentyna Gapon, Lyudmyla Chimbay, Olena Barabash

\title{
EXPERIENCE OF DEVELOPING AND FUNCTIONING OF THE DISTRIBUTED INFORMATION DATABASE WITH ORGANIZATIONAL AND REGULATORY INFORMATION OF THE MINISTRY OF EDUCATION AND SCIENCE OF UKRAINE
}

\begin{abstract}
The article describes the experience of creating a distributed database with organizational, regulatory, normative and legal documents of the Ministry of Education and Science of Ukraine, regulating the activity of the system of education and science. The improvement of legislative regulation, the development of numerous drafts of legislative acts and the amendments to existing normative and legal acts are the primary tasks of any reform. The problems of the development of information space, lack of implementation of information and communication technologies in the field of education, science and culture are highlighted. The article analyzes the experience of domestic and foreign scientists in the development of information and communication systems. The problems of creating an ordered bank of normative documents and methodical materials in educational and management activities have been researched. It is noted that information resources are one of the main components of the information and communication system, which provides access, information exchange and processing. Integration of ICT in the education sector not only affects educational and managerial processes, but also introduces new ones that are connected with the use of computers, telecommunications, special equipment, information exchange tools, information processing systems. The main stages of creation and features of the information retrieval system support have been analyzed. The authors determine the criteria for choosing a technical platform for the construction of an information database and the indicators for structuring information. The article presents the technological scheme of information retrieval system with the normative and legal documentation and describes in detail the characteristics of the technological platform of the client and server parts. The logical structure of the database and the basic information specifying the structure of the relational tables are given. The article provides information on the availability of documents in the database and analyzes the distribution of documents by composition.
\end{abstract}

Keywords: information retrieval system, relational databases, education system, electronic documents. 